\title{
Forecasting Underground Water Dynamics within the Technogenic Environment of a Mine Field. Case Study
}

\author{
Oleg Bazaluk ${ }^{1}$, Ivan Sadovenko ${ }^{2}$, Alina Zahrytsenko ${ }^{2}$, Pavlo Saik ${ }^{3}$, , Vasyl Lozynskyi ${ }^{3, *(\mathbb{D})}$ \\ and Roman Dychkovskyi ${ }^{3}$ \\ 1 Belt and Road Initiative Institute for Chinese-European Studies (BRIICES), Guangdong University of \\ Petrochemical Technology, Maoming 525000, China; bazaluk@ukr.net \\ 2 Department of Hydrogeology and Engineering Geology, Dnipro University of Technology, \\ 49005 Dnipro, Ukraine; sadovenko.i.o@nmu.one (I.S.); zahrytsenko.a.m@nmu.one (A.Z.) \\ 3 Department of Mining Engineering and Education, Dnipro University of Technology, 49005 Dnipro, Ukraine; \\ saik.nmu@gmail.com (P.S.); Dychkovskyi.r.o@nmu.one (R.D.) \\ * Correspondence: lvg.nmu@gmail.com
}

check for

updates

Citation: Bazaluk, O.; Sadovenko, I.; Zahrytsenko, A.; Saik, P.; Lozynskyi, V.; Dychkovskyi, R. Forecasting

Underground Water Dynamics within the Technogenic Environment of a Mine Field. Case Study. Sustainability 2021, 13, 7161. https://doi.org/ $10.3390 /$ su13137161

Academic Editors: Zoran Kovač and Stanko Ružičić

Received: 12 May 2021

Accepted: 22 June 2021

Published: 25 June 2021

Publisher's Note: MDPI stays neutral with regard to jurisdictional claims in published maps and institutional affiliations.

Copyright: (c) 2021 by the authors. Licensee MDPI, Basel, Switzerland. This article is an open access article distributed under the terms and conditions of the Creative Commons Attribution (CC BY) license (https:// creativecommons.org/licenses/by/ $4.0 /)$.

\begin{abstract}
The objective is to analyze the dynamics of the underground water of a mine field based on the study of the geofiltration process of the rock mass disturbed by mining to achieve safe extraction operations as well as subsurface territories at the stage of the mining enterprise closure. Numerical modeling, based on a finite difference method under the conditions of multifactority and definite uncertainty of processes of transformation of technogenic environment of a mine field, helps solve a problem concerning underground water dynamics forecasting. A hydrodynamic model of the M.I. Stashkov mine was developed while solving option series of epignosis problems in terms of the chronology of mine field stoping. The abovementioned made it possible to identify regularities of the history of filtration, the capacity parameters of rock mass and the expansion of areas of heightened hydraulic conductivity as well as to evaluate qualitatively the water balance components of a carbonic watered formation and an overlying one. The stage of mining closure helped obtain the forecasting hydrodynamic solutions. The efficiency of measures, concerning reduction of water ingress into mine workings and the mitigation of surface ecological effects of mine flooding was evaluated quantitatively. It was determined that implementation of the water control procedures makes it possible to perform a $10-38 \%$ decrease in water ingress. In this context, they may be applied both independently and simultaneously. In terms of mine closure and flooding, a period of complete underground water recovery takes three years; in the process, surface zones of potential waterlogging and swamping are developed within the floodplain of Samara River, located at the territory of Western Donbas (Ukraine). The scientific novelty is to define regularities of hydraulic conductivity transformation of the rock mass of a mine field starting from the mine working roof fall, up to its compaction during the mine operation period. To do that, nonstationary identification problems were solved, using numerical modeling. The abovementioned makes it possible to improve the reliability of hydrodynamic prognoses and develop technological schemes to control water at the state of the mine closure.
\end{abstract}

Keywords: underground water; mine; geofiltration; modeling; hydrodynamic

\section{Introduction}

Researchers consider a process of underground coal mining as one of the major technogenesis types that is comparable with geogenesis in terms of intensity and metamorphosis depth $[1,2]$. Large-scale transformations of rock mass factor lead to changes in the state and characteristics of both the subsurface [3-5] and the whole environment [6,7]. Underground water is the basic dynamic subsurface component helping to perform energy, mass, and heat transfer [8,9] as well as to transfer common groundwater contaminants [10-13]. Water can vary the properties of the geosystem and environment [14], and activate exogenic 
processes and even endogenic ones [15,16]. Forecasting of hydrodynamic changes in the underworked rock mass and prevention of their negative effects are relevant scientific and practical problems [17-21].

Geomechanical processes, arising in the rock mass in the process of mining with complete gob caving, vary the physicomechanical characteristics of the rock mass [22-25]. Technogenic fissuring progresses within the caving areas, resulting in the increased hydraulic conductivity as well as in the increased capacity properties of the rock mass that experiences permanent temporal variations during the whole period of the deposit operation [26-28]. In terms of a part of the Donetsk coal basin (Central Donbas, Ukraine) and steep pitch, the authors of papers $[29,30]$ identified that under the influence of changes in geomechanical processes in rock mass, stipulated by its repeated underworking, the hydraulic conductivity varies according to hyperbolic dependence with stabilization at $10^{-7}-10^{-6} \mathrm{~m}^{2}$ level.

In this context, the filtration coefficient of rocks experiences almost a 100-times increase; the gravitation capacity increases up to 14 times; and the infiltration supply increases up to 3.5 times. Within the areas of tensile strain concentration, rock disintegration increases 1.2-1.4 times. At the same time, the compression strain is 1.6 times more than the tensile one, resulting in rock solidification and hydraulic conductivity bed formation [31].

Studies, described by paper [32], showed how changes in the geomechanical situation of the rock mass influence its state. It was identified that the major rock mass changes take place at a distance from the mine working periphery of up to five times its radii. An increase in the distance between the fissures from $0.5 \mathrm{~m}$ up to $1.5 \mathrm{~m}$ decreases the filtration coefficient in the mine working neighborhood by $25-50 \%$.

Paper [33] evaluated the formation of a secondary aquifer according to the results of observations about the movement and compaction of caved rocks. The compaction of the caved rocks and their cementation comprises three periods; mainly, the processes depend upon the load being developed after the rock moves to a day surface. The period of the rock movement to a day surface is 2 to 6 months after the stope displacement. In this context, the authors believed that new structures, having other filtration properties, are formed. However, they did not specify their quantitative characteristics.

The majority of the studies concern the analysis of the filtration parameters of the rock mass at the stage of active displacements and the formation of zones of water conducted fissures [34-36]. Moreover, they differ by orders of magnitude in terms of various data [37]. Hence, they are not common depending upon specific mining-geological and technological conditions of coal extraction [38-40]. The problem of the transformation of filtration and capacity characteristics of mined-out areas remains uncertain over 40-60 years of a coal deposit operation; nevertheless, their influence on the reliability of hydrogeological forecasts is determinative [41].

Under the conditions, complicated by numerous factors with many unknowns, digital mathematical modeling of geofiltration is perhaps the only justified method to analyze the rock mass of a mine field disturbed technogenically.

The idea is also supported by the authors of paper [42], who dealt with the development of the hydrodynamic model of the Central Donbas area where mine fields are connected hydraulically. Surface waterlogging areas, being almost $33 \%$ of the territory, were identified in terms of the results of prognosis modeling of successive and simultaneous mine floods. A differential approach was proposed to select the drainage measures protecting the mine field surfaces against waterlogging.

A numerical model of a technogenically disturbed rock mass within the Kuznetsk coal field was developed by the authors of paper [43] to evaluate the amount of underground water in the zone of drainage impact of underground mine workings. At the same time, the geofiltration model developed by the authors of paper [44] is the basis to evaluate the capacity amount of underground water in the flooded mine as well as to forecast changes in the hydrodynamic mode while using the water as a heat carrier with the help of a thermal power module. 
In the context of mining regions, the technogenic mode of underground water is characterized by the breach of hydrodynamical, hydrochemical, and thermal behavior; it is notable for its specific dynamisms and dependence upon mining and geological factors [45-48].

It should be mentioned that each mining region in Ukraine and in the world has similar features of technogenic changes in the underground and surface hydrosphere [49-53]. They are manifested as the formation of subaerial subsidence troughs and waterlogging areas, quantitative and qualitative troubles in the functioning of the drinking water abstraction, and ground water contamination due to infiltration losses from containment ponds $[54,55]$. At the same time, solving the problem of safe mining under conditions of complex and multi-factor geofiltration processes is still relevant [56,57], especially during the closure of a mining enterprise [41]. Hence, the research objective is to analyze the dynamics of the underground water of a technogenic medium of a mine field to achieve the safety of extraction operations and near-surface territories at the stage of closure of a mining enterprise.

To succeed, the following problems should be solved:

- The substantiation of a scheme of a geofiltration numerical model of a mine field, taking into consideration both natural and technogenic factors of underground water mode formation;

- The identification of basic factors forming water ingress in a mine as well as the regularities of the transformation of filtration parameters of the disturbed rock mass;

- The determination of the influence of the mine working flooding on the ecological state of the neighboring territories and substantiation of engineering measures of water control.

While solving nonstationary identification problems using a numerical model and determining regularities of the hydraulic conductivity transformation of the mine field rock mass starting from the moment of the mine working roof fall, up to its solidification along the mine operation period, we can be sure in reasoning the scientific novelty of the paper, as it will help improve the reliability of the hydrodynamic prognoses and develop scientifically substantiated technological schemes of water control at the mine closure stage.

\section{Methodology}

Scientific and technical approaches to model geofiltration within coal deposits were substantiated in terms of the hydrodynamically open type of the M.I. Stashkov mine (Donetsk coal basin "Donbas", Ukraine) where coal seams have an active hydraulic connection with the thick formation of waterflooded Meso-Cenozoic rocks. Figure 1 shows the geographic location of the site under study.
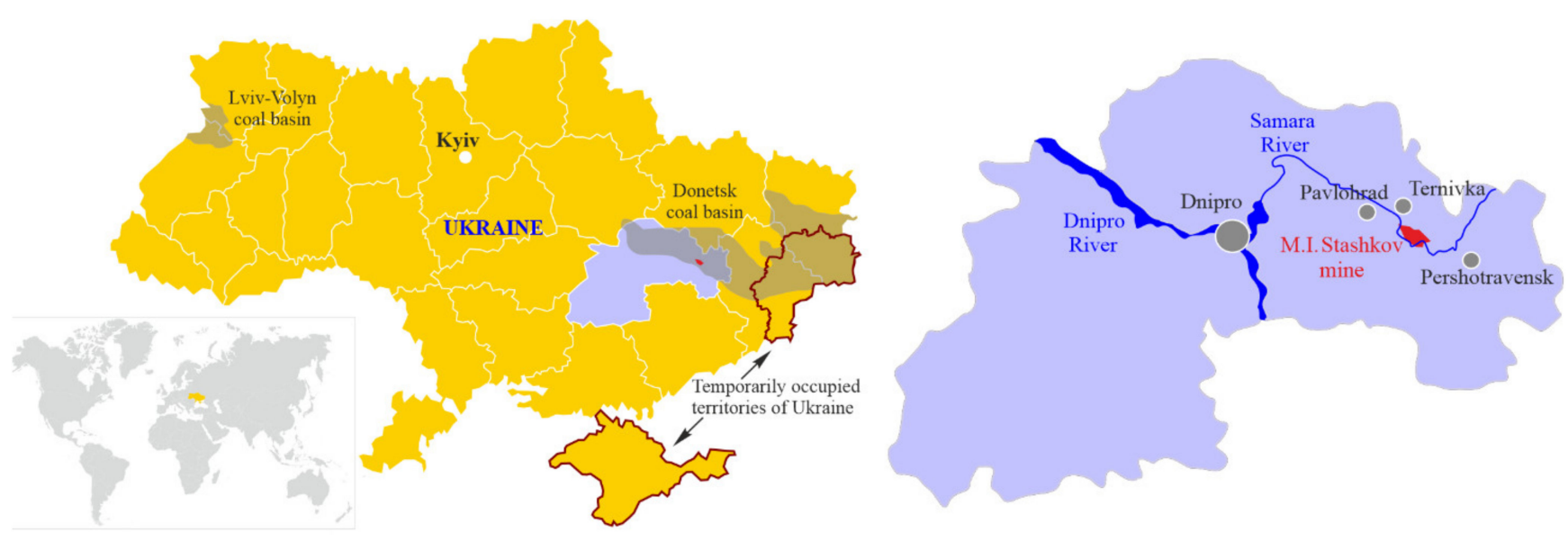

Figure 1. Geographic location of the site under study (map of coal basins of Ukraine and M.I. Stashkov mine arrangement. The map was adapted using scientific sources [58,59]). 
The hydrodynamic situation of a part of the deposit is complicated by coal occurrence in inundable river portions where the surface watercourse may be an additional formation source of inflows into mine workings and the floodplain is a zone of potential waterlogging in the process of a mine closure and the recovery of the underground water level.

The algorithm to model numerically a technogenic mode of underground water is based upon differential filtration Equation (1), solved by means of numerical iteration methods with the help of a system of finite-difference equations:

$$
T_{x} \frac{\partial^{2} H}{\partial x^{2}}+T_{y} \frac{\partial^{2} H}{\partial y^{2}} \pm W=\mu^{*} \frac{\partial H}{\partial t}
$$

where $H$ is the unknown pressure function; $W$ is the feeding (discharge) throughout the aquifer; $T_{x}, T_{y}$ are the conductivity of the aquifer in terms of linear coordinates $x$ and $y$, respectively; $\mu^{*}$ is the coefficient of the elastic water yield; and $t$ is time.

The finite-difference approximation of Equation (1) is based upon the spatial and time-dependent discrete representation of a geofiltration flow in terms of which continuous filtration field $H(x, y, z)$ is replaced by an imaginary network area characterized by $H\left(x_{j}, y_{i}, z_{k}\right)$ pressure values in each node of the network per time moments with $\Delta t$ interval:

$$
\frac{H_{j-1, i}^{t}-H_{j, i}^{t}}{\Phi_{j-1, j}}-\frac{H_{j, i}^{t}-H_{j+1, i}^{t}}{\Phi_{j, j+1}}+\frac{H_{j, i-1}^{t}-H_{j, i}^{t}}{\Phi_{i-1, i}}-\frac{H_{j, i}^{t}-H_{j, i+1}^{t}}{\Phi_{i, i+1}} \pm W_{j, i} \Delta x_{j} \Delta y_{i}=\mu_{j, i} \Delta x_{j} \Delta y_{i} \frac{H_{j, i}^{t}-H_{j, i}^{t-\Delta t}}{\Delta t},
$$

where $\Phi$ is the filtration resistance of the flow between analytical blocks expressed through $\Delta x, \Delta y$, block geometry and conductivity values.

Papers [60-62] specify general methods of the development of the numerical, mathematical geofiltration model involving several stages, among which are the following:

- Systemization of data of mining and geological conditions;

- The model identification in terms of the physical and dynamical analogy of the object;

- Forecasting solutions (generally, integrity of the latter is identified by means of the schematization quality of the conditions as well as the model verification).

Figure 2 represents the schematic modelling methods of geofiltration processes within the mine field.

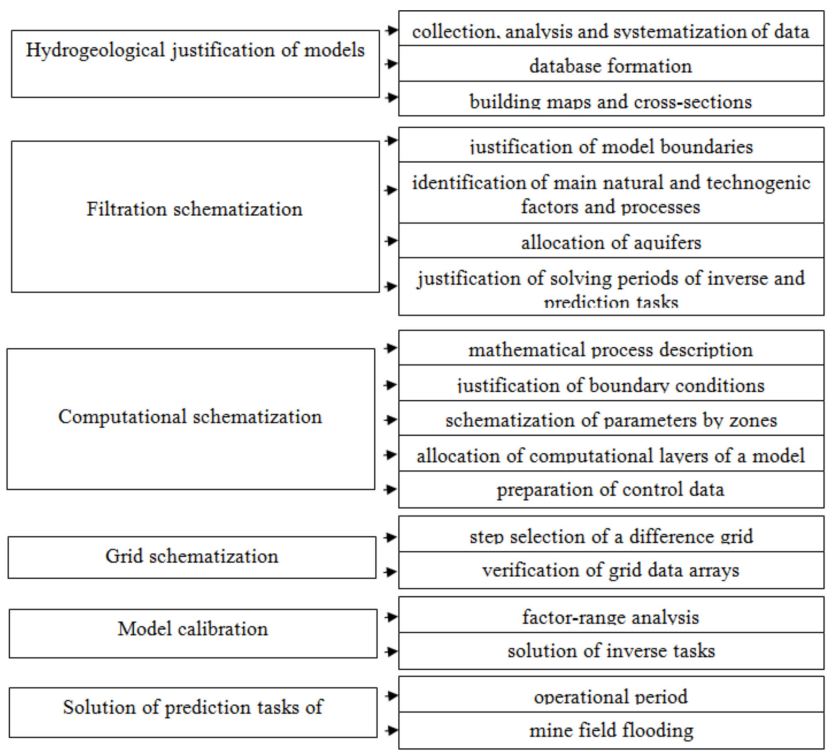

Figure 2. Schematic representation of the methods to develop mathematical models of a mine field.

To solve differential equations of geofiltration and to model the filtration processes, the authors applied the MIFp software developed in Ukraine by a branch laboratory of hydrogeological studies of the Dnipro Department of the Ukrainian Geological Prospecting 
Institute. The software is protected by copyright; unfortunately, it cannot be sent through the internet. In turn, it is used to solve various hydrogeological problems starting from the evaluation of underground water reserves up to the assessment of the disturbed mode of underground water within mining regions. The program was tested while solving hydrogeological problems of mine closure in the Central Donbas area and hydroecological problems of the Kryvyi Rih iron-ore field (Ukraine). The results of early studies, published in $[41,57,63]$, were obtained using corresponding software; their validity was confirmed practically.

The software is meant for numerical solutions of differential equations describing processes of plane and spatial filtration as well as mass transfer within nonhomogeneous stratified formation, involving the following: interaction of underground and surface water; migration through separating layers; infiltration feeding; evaporation depending upon the ground water depth; water surface entering; operation of water wells and pumping wells; time-dependent changes in boundary conditions and parameters; transition of a pressure filtration mode into a pressureless one and vice versa; layer thinning; water conductivity dependence of pressureless levels upon the underground water level; and rock anisotropy. The algorithm advantage is the possibility to represent the thinning (outcrop under the overburden rocks) of coal seams, being the determining factor while forming the water inflow into the mine workings.

The representation of the aquiferous complex of overburden deposits as well as natural and technogenic coal systems has become an important stage in the process of mine-field model development. The abovementioned has made it possible to use the model as a permanent one for each operating stage of a mining enterprise while responding promptly to rapid changes in a hydrogeological situation and solving engineering problems to optimize water control measures.

\subsection{Analysis of Natural and Technogenic Conditions, and Substantiation of Hydrodynamic Scheme of a Mine Field Model}

The analyzed mine field is within the Dnipropetrovsk Region (Ukraine) in the Samara River basin; its area is almost $83.6 \mathrm{~km}^{2}$.

The mine field territory is represented by slightly hilled plain separated by a river and ravine network. The Samara River crosses the mine field, dividing it into two uneven shares: large- - a right-bank part being 30-80 m higher than the floodplain, and small-a left bank part represented by the floodplain where absolute marks are $+62 \ldots+72 \mathrm{~m}$.

The structure section consists of two hydrogeological levels. The upper one involves Meso-Cenozoic overburden deposits represented by loose sandy and clay Paleogene rocks (Bucha, Kyiv, and Kharkiv measures); Neogene rocks (Sarmatian measures); and Quaternary rocks (Figure 3). The formation thickness varies from $40 \mathrm{~m}$ in the Samara River valley up to $140 \mathrm{~m}$ within a watershed.

Meso-Cenozoic deposits do not include continuous impermeable layers. Hence, all water-bearing strata are interconnected, forming a unified aquifer system. Under the natural conditions, its supply was performed at the expense of atmospheric precipitation infiltration; the water drained into the Samara River and its feeders.

The lower hydrogeological level is represented by a coal measure of the Mississippian period. The thickness of the layer is up to $410 \mathrm{~m}$; it is the key productive formation in Western Donbas. Underground water is confined to coal, sandstone, and limestone seams, alternated with impermeable argillite and aleurite. Water of the deposits is fissure-stratal and pressured. The filtration coefficient of the sandstone and coal varies in a broad range; its average value is $0.74 \mathrm{~m} /$ day. The natural hydraulic conductivity of the rocks decreases in a structured section; depths deeper than 250-300 m unwatered coal and sandstone are prospected.

In the process of the geofiltration model development, the mine field is approximated with the help of grid with $77 \times 43$ cells (Figure 4 ). As for the actual conditions, the geometry of the mine field is $15.4 \times 8.6 \mathrm{~km}$. Each grid point represents the seam hypsometry as well as the filtration and capacity parameters of both aquifers and separating formations. 


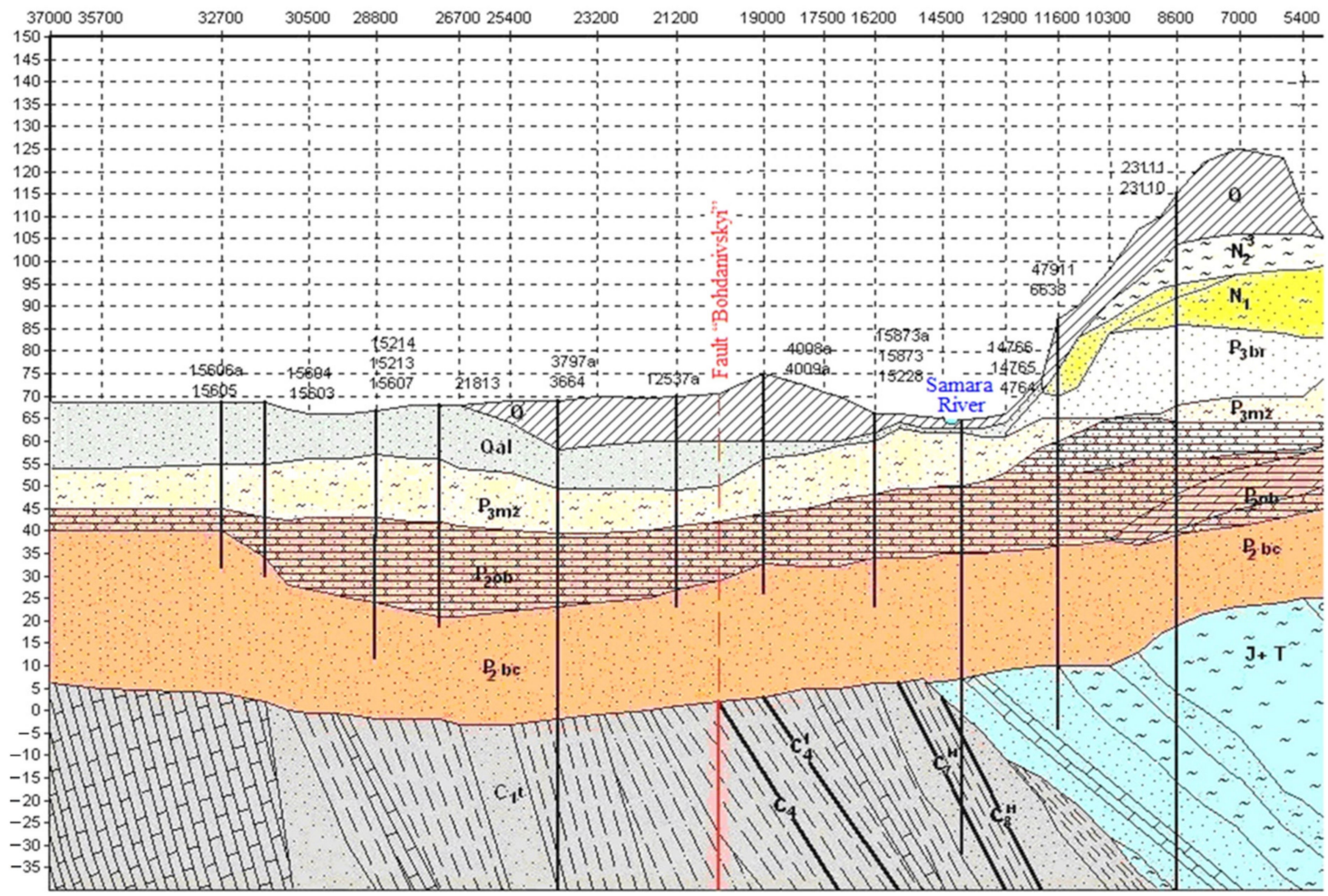

Figure 3. Geologic section of the study area (south-west to north-east).

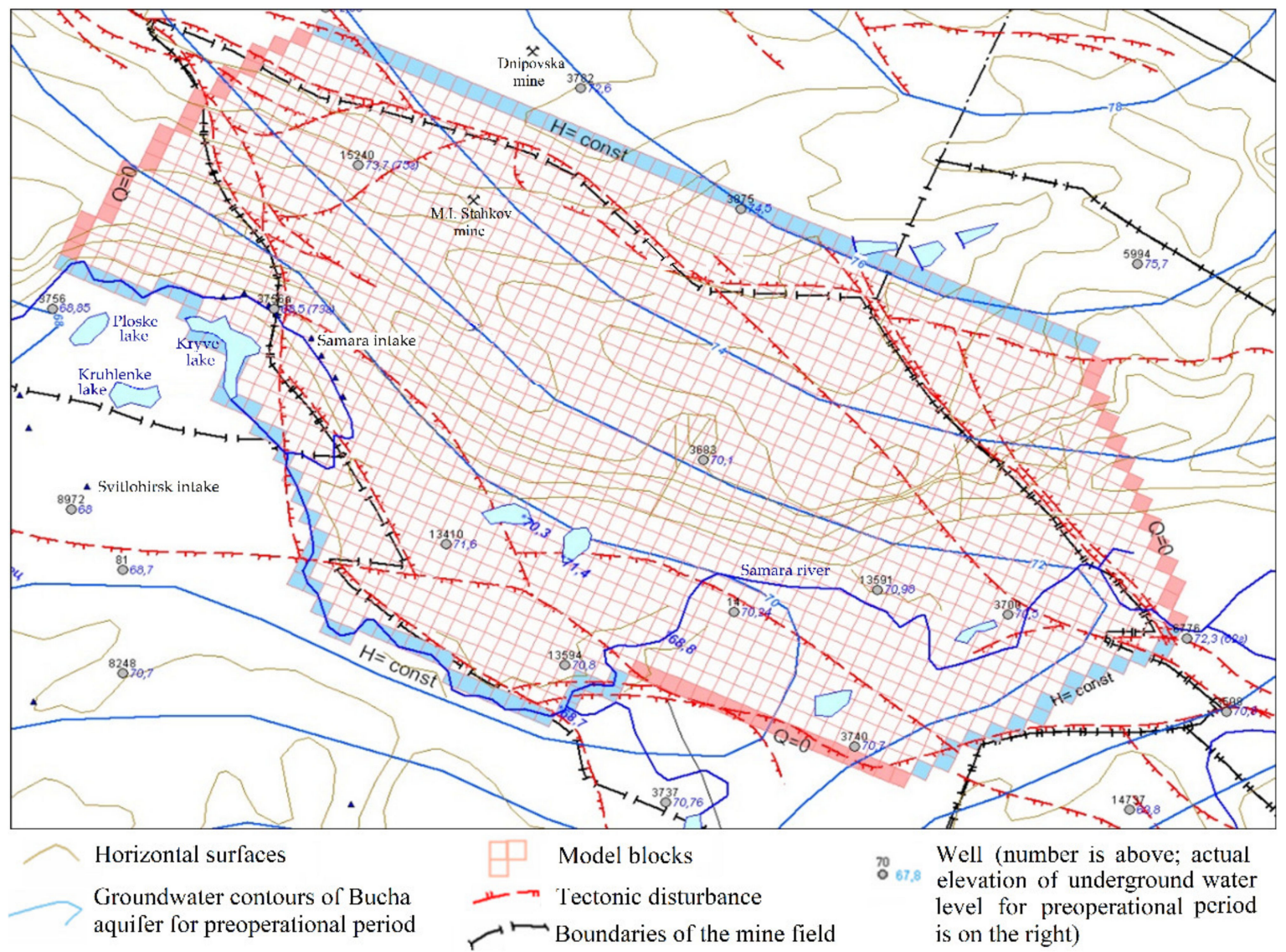

Figure 4. Geometry of upper aquifer system and its boundaries (1 analytical layer of the model). 
The most watered sandstone with 30-50 m thickness occurs within the roof of the $\mathrm{C}_{5}+\mathrm{C}_{5}{ }^{\mathrm{B}}$ coal seam. The sandstone outcrops under Meso-Cenozoic deposits. In terms of the feature complex, the mineral is characterized as alluvial or channel. Since the mine is of a hydrodynamically open type, in addition to capacity reserves, the water inflow is formed owing to the involved resources at the expense of the flow of overburden deposit aquifers as well as the surface water inflow. The representation of coal seam mining within productive carbon formation to involve the actual hydraulic connection between the upper and lower hydrogeological levels was performed with the help of mine field contouring in terms of $\mathrm{C}_{10}, \mathrm{C}_{8}, \mathrm{C}_{7}, \mathrm{C}_{6}, \mathrm{C}_{5}, \mathrm{C}_{4}$, and $\mathrm{C}_{1-3}$ coal layers (Figure 5). The abovementioned has made it possible to define extra feeding within the outcropping areas of the coal seams as well as the paleochannel sandstone under Meso-Cenozoic deposits.

Hence, within a vertical section, the mine field model is represented by means of 8 layers, where upper layer 1 demonstrates the aquifer system of overburden Bucha-Kyiv deposits, and 2-8 layers show the mined-out coal seams and paleochannel sandstone $\mathrm{C}_{10}$, $\mathrm{C}_{8}, \mathrm{C}_{7}, \mathrm{C}_{6}, \mathrm{C}_{5}, \mathrm{C}_{4}$, and $\mathrm{C}_{1-3}$, outcropping directly under layer 1 (Figure 6a).

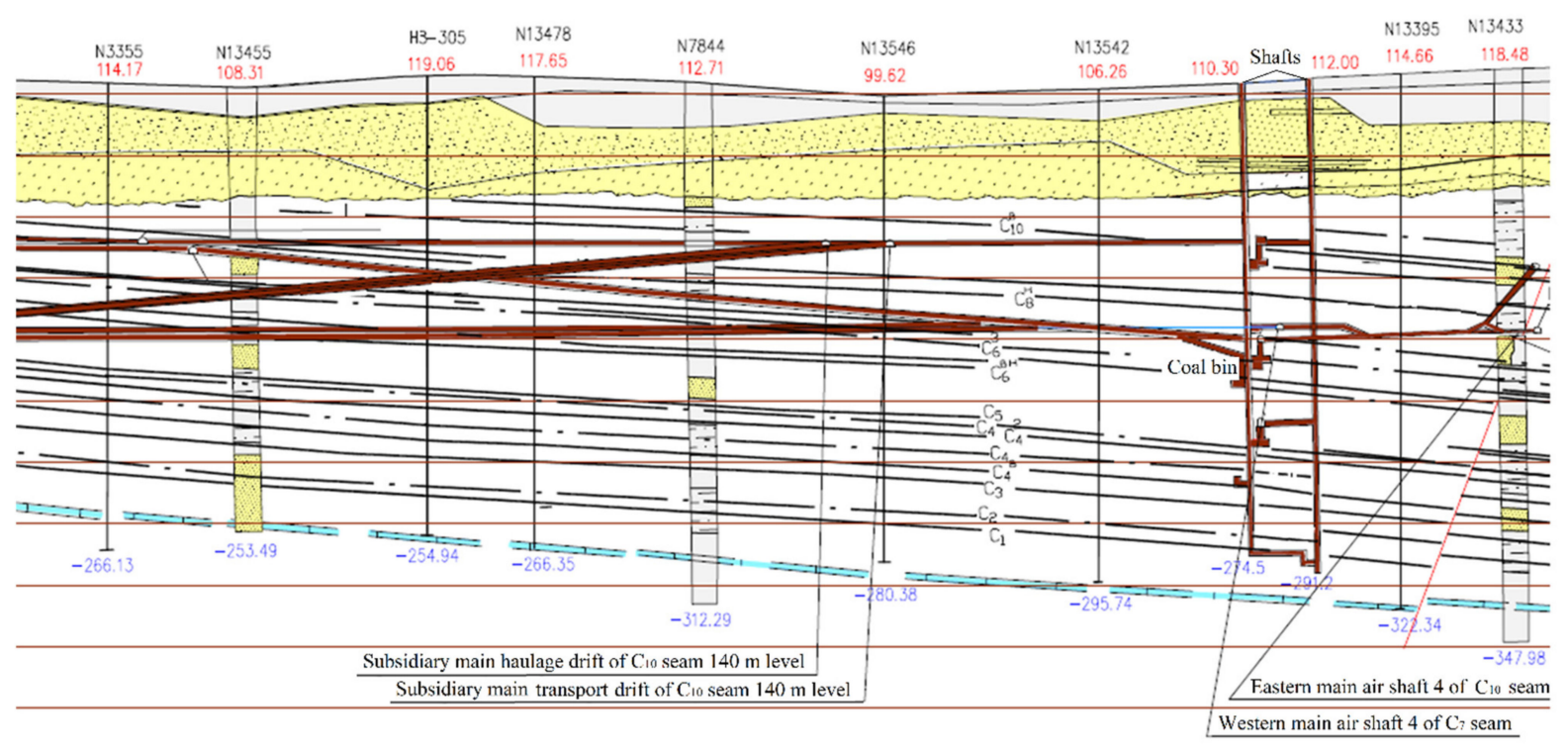

Figure 5. Fragment of a scheme of the mine field development.

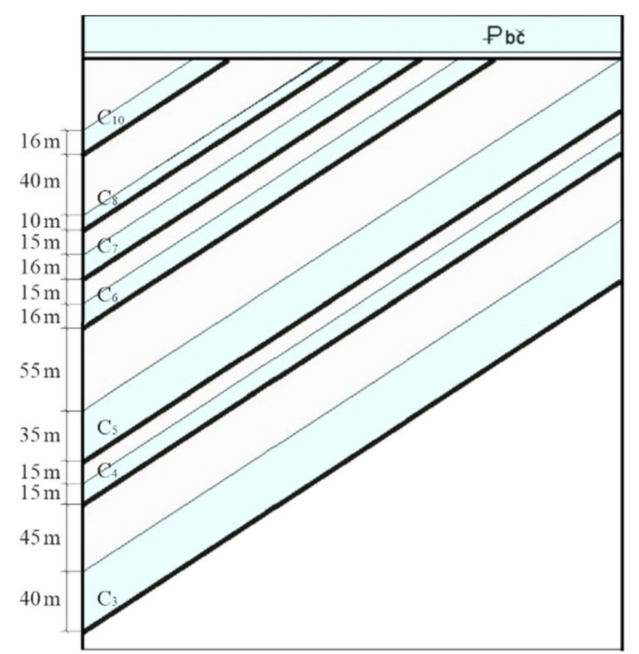

(a)

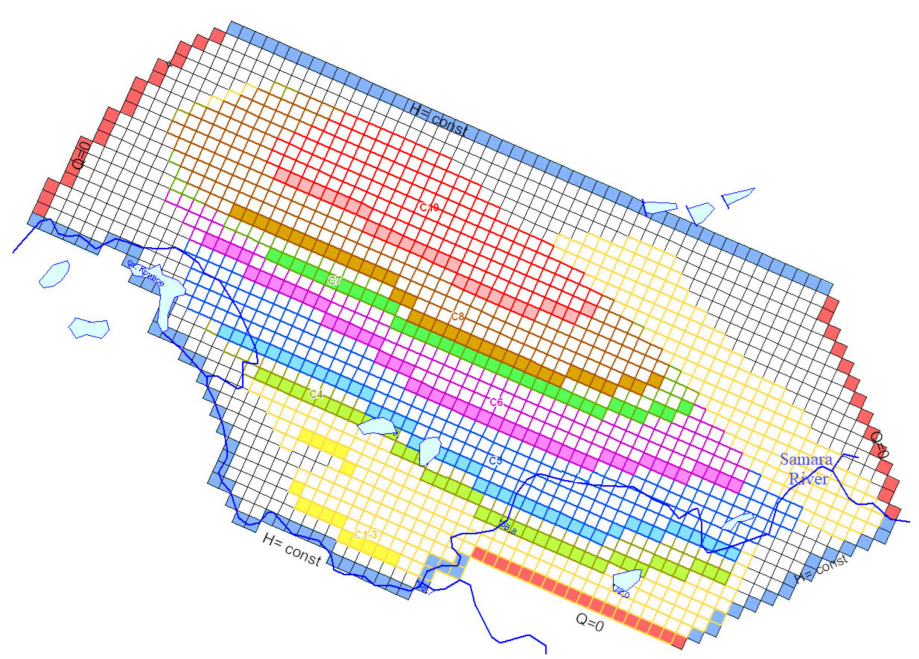

(b)

Figure 6. The model scheme in terms of a structural section (a) and in terms of a plan (b). 
The external hydrodynamic boundary of analytical layer 1 of Bucha-Kyiv deposits (Figure 4) demonstrates the natural feeding system as well as the underground flow into the Samara River (Derichlet's boundary condition, $H=$ const). In terms of flow lines, Newmann's boundary condition with zero loss $(Q=0)$ is specified.

In the plan, hydrodynamic boundaries of coal seams (analytical layers 2-8) coincide with the mine field boundary determined in terms of zones of tectonic disturbances (i.e., Pozdovzhnyi, Petrovskyi, Bohdanivskyi, and Nikolskyi faults). They are impermeable barriers for underground water filtration $(Q=0)$. The boundary of the coal seam outcrop under the watered formation (Figure $6 \mathrm{~b}$ ) is specified by Newton's boundary condition $(H=f(Q))$, representing the interconnection between the levels and losses resulting from mine drainage.

To represent the natural mode of ground water, the boundaries are specified along the flow lines (i.e., perpendicularly to hydroisohypses); at the stage of hydrodynamic changes, they are not waterproof barriers. The river has water-permeable underflow deposits; hence, its impact on the water inflow into mine workings is recorded when mining operations approach the coal seam outcrop under the floodplain. As for the role of tectonic displacements within the carbonous formation, practices of their crossing by mine workings mean that they are waterproof barriers for underground water.

Internal boundaries of the model are represented by mine workings, being also a drainage contour for sandstone occurring within the immediate roof or within the water fissure zone. In this context, sandstone is considered part of the mine working, i.e., as a drainage periphery with the specified level of underground water decrease at a mark of the coal seam floor. The model scheme has helped to involve the hydraulic connection between the carbonous formation and overburden deposits as well as a prerequisite concerning the availability of the paleochannel (i.e., alluvial) sandstone within the coal seam roof.

\subsection{Identification of the Model}

The most important stage to develop a mine field model involves solving identification or epignosis problems in terms of the natural hydrodynamic situation and in terms of the situation disturbed by mining. Then the solutions are applied to specify the boundary conditions, filtration parameters, and capacity parameters, using the underground water level as well as water rate inflows.

Finally, the identification results of the mine field model are evaluated in terms of the object functioning data, i.e., functional correspondence is determined when the model reproduces the processes for which the actual behavior was recorded under the natural conditions. The development process of the mine field model reproduces the chronology of coal seam mining during the periods in which were recorded the most typical changes in water inflows (Figure 7).

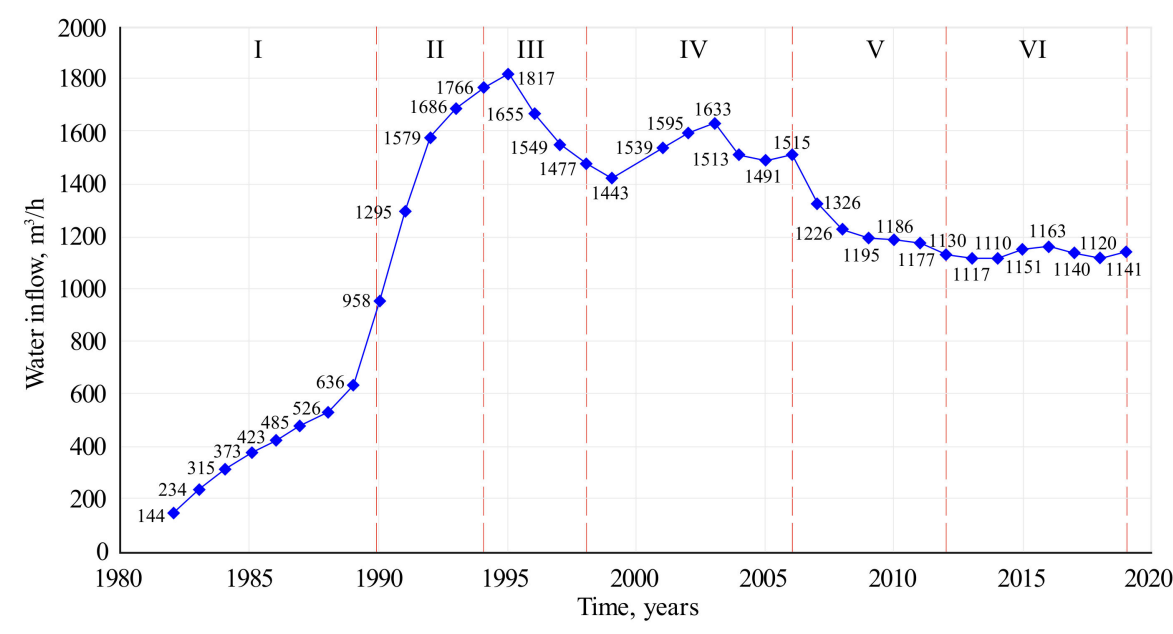

Figure 7. Dynamics of mine water inflow formation $\left(\mathrm{m}^{3} / \mathrm{h}\right)$ : I-VI-periods. 
The verification process of the mine field model identifies the reliability of the forecasted solutions as well as the water control efficiency at the stage of the deposit operation and at the stage of mine closure.

\section{Results and Discussion}

A process of natural hydrodynamic pattern reproduction, using the developed mine field model for the mine preoperational period helped to support the reliability of the actual underground water data as well as to balance the numerical model (Table 1).

Table 1. Comparison of the modeling results and actual data of the underground water level for a preoperational period.

\begin{tabular}{|c|c|c|c|c|c|c|}
\hline \multirow{2}{*}{ No. } & \multirow{2}{*}{$\begin{array}{c}\text { Geological Index of } \\
\text { the Rocks }\end{array}$} & \multirow{2}{*}{ Well } & \multirow{2}{*}{$\begin{array}{l}\text { Number of } \\
\text { Analytical Blocks } \\
\text { of the Model }(x / y)\end{array}$} & \multirow{2}{*}{$\begin{array}{l}\text { Wellhead } \\
\text { Elevation, m }\end{array}$} & \multicolumn{2}{|c|}{$\begin{array}{l}\text { Underground Water Elevation, } \mathrm{m} \\
\text { (Years of 1954-1980) }\end{array}$} \\
\hline & & & & & Object & Model \\
\hline 1 & $\mathrm{P}_{2} \mathrm{kv}+\mathrm{bc}$ & 3782 & $11 / 4$ & 76.8 & 72.6 & 74.3 \\
\hline 2 & $\mathrm{P}_{2} \mathrm{kv}+\mathrm{bc}$ & 3875 & $37 / 3$ & 76.1 & 74.5 & 75.4 \\
\hline 3 & $\mathrm{P}_{2} \mathrm{kv}+\mathrm{bc}$ & 13,410 & $30 / 30$ & 73.5 & 71.6 & 69.3 \\
\hline 4 & $\mathrm{P}_{2} \mathrm{kv}+\mathrm{bc}$ & 13,594 & $40 / 34-35$ & 72.0 & 70.8 & 69.2 \\
\hline 5 & $\mathrm{P}_{2} \mathrm{kv}+\mathrm{bc}$ & 3740 & $57-58 / 32$ & 72.2 & 71.6 & 70.6 \\
\hline 6 & $\mathrm{P}_{2} \mathrm{kv}+\mathrm{bc}$ & 13,591 & $54 / 22-23$ & 71.9 & 70.9 & 70.7 \\
\hline 7 & $\mathrm{P}_{2} \mathrm{kv}+\mathrm{bc}$ & 13,564 & $65 / 13-14$ & 73.2 & 71.8 & 71.9 \\
\hline 8 & $\mathrm{P}_{2} \mathrm{bc}$ & 3700 & $62 / 20-21$ & 72.7 & 70.4 & 70.9 \\
\hline 9 & $\mathrm{P}_{2} \mathrm{bc}$ & 14 & $48 / 27$ & 71.8 & 70.2 & 69.7 \\
\hline 10 & $\mathrm{P}_{2} \mathrm{bc}$ & 3683 & $42 / 19$ & 126.7 & 70.1 & 71.2 \\
\hline 11 & $\mathrm{P}_{2} \mathrm{bc}$ & 15,573 & $57 / 17$ & 82.3 & 71.0 & 71.9 \\
\hline 12 & $\mathrm{P}_{2} \mathrm{bc}$ & $3756 a$ & $14 / 20-21$ & 74.0 & 68.5 & 68.3 \\
\hline 13 & $\mathrm{C}_{1}$ & 3787 & $18 / 7$ & 121.6 & 70.4 & 70.4 \\
\hline 14 & $\mathrm{C}_{1}$ & 3849 & $29-30 / 15$ & 135.9 & 71.5 & 70.9 \\
\hline 15 & $\mathrm{C}_{1}$ & 1313 & $43 / 11$ & 138.1 & 73.5 & 72.5 \\
\hline 16 & $\mathrm{C}_{1}$ & 3681 & $43 / 19$ & 126.8 & 70.2 & 70.2 \\
\hline 17 & $\mathrm{C}_{1}$ & 15 & $48 / 26$ & 71.8 & 70.6 & 70.1 \\
\hline 18 & $\mathrm{C}_{1}$ & 3739 & $57-58 / 32$ & 73.5 & 70.7 & 70.4 \\
\hline 19 & $\mathrm{C}_{1}$ & 1334 & $63 / 20$ & 72.6 & 70.9 & 71.0 \\
\hline
\end{tabular}

It was determined that under natural conditions, the underground water of the BuchaKyiv deposit flows into the Samara River. The fact is supported by the groundwater contour near the river as well as by the moving direction of underground flows (Figure 4). The Samara intake operation with $2000-3200 \mathrm{~m}^{3}$ / day of water discharge is a development pressure source for the period.

The research results, connected with the model response to fluid dynamic excitation by means of the introduction of Derichlet's boundary condition, according to the mining schedule, showed that in terms of each period, the underground water level of overburden deposits corresponds to actual ones $\left(Q_{a c t}\right)$ as well as the recorded water inflows $\left(Q_{r e c}\right)$ (Figure 8).

The average error of the solution is not more than $10 \%$ in terms of the water inflow rate; it is $7 \%$ in terms of the level. In this context, the mismatch of the total model balance is not more than $0.01 \%$. Hence, in accordance with mining schedules, the authors characterize periods of coal seam mining where the most typical changes in water inflows were recorded.

The results of the monitoring observations in terms of the 3756a well, represented in Figure 9, are the control data for the changes in the underground water level in the Bucha aquifer in the process of coal seam mining. 


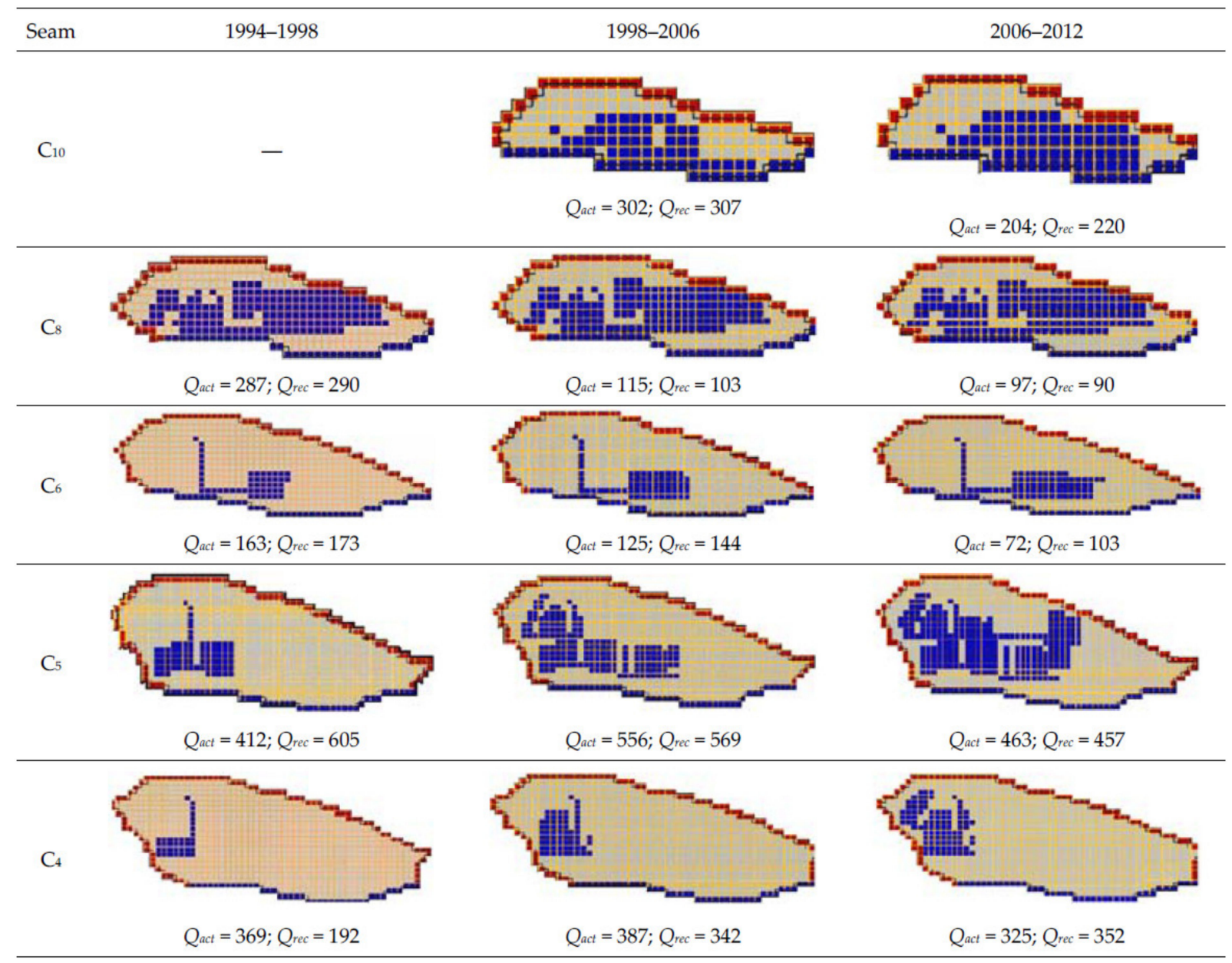

Figure 8. Dynamics of mining operations and water inflows in terms of periods.

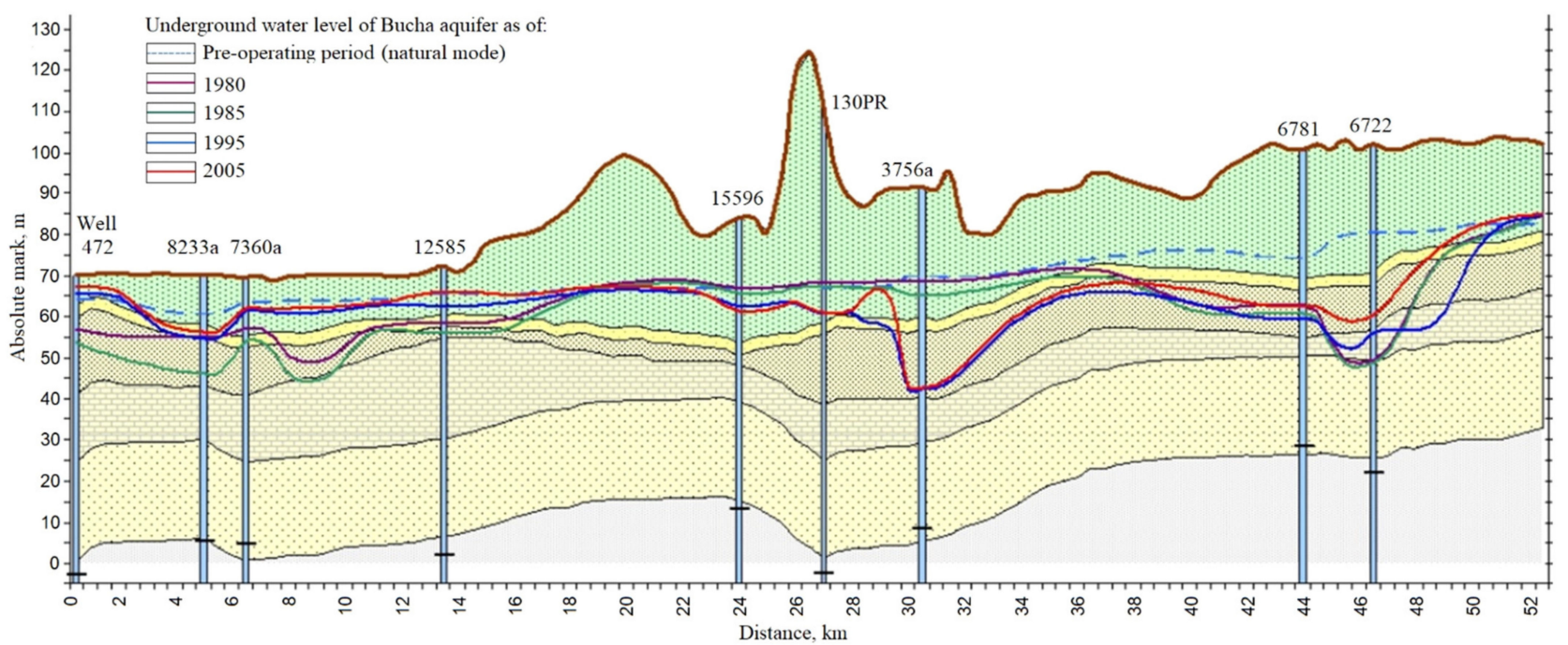

Figure 9. Schematic hydrodynamic profile of Western Donbas (west-east).

Period 1 (years of 1982-1990) is characterized by the hydrodynamic influence of coal seam $\mathrm{C}_{8}$ mining, and the drive of main haulage roads within seam $C_{10}$. Water inflow into mine workings of the $C_{8}$ seam is $373.3 \mathrm{~m}^{3} / \mathrm{h}$, where $90.5 \mathrm{~m}^{3} / \mathrm{h}$ (i.e., $24 \%$ ) of the inflow falls at a leakage from the Samara River. The fact stipulates the formation of a conical depression in the Bucha-Kyiv aquifer as well as corresponding changes in feeding and draining. 
Changes in the direction of filtration flows show that from a zone of underground water drainage, the river transforms into a feeding zone of the Bucha-Kyiv aquifer (Figure 10). A decrease in the underground water level in the Bucha deposits achieves $13.5 \mathrm{~m}$, relative to the preoperational state.

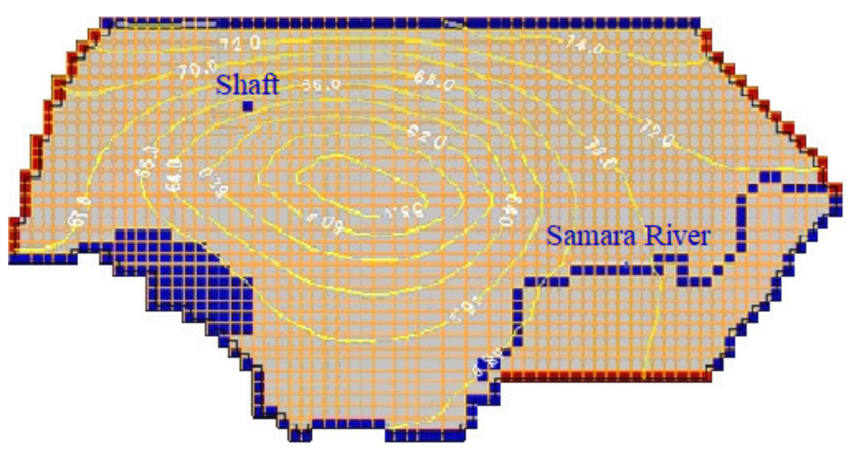

Figure 10. Map of groundwater contours (elevation, $\mathrm{m}$ ) of the aquifer within Bucha-Kyiv deposits (data for the first calculated period).

Period 2 (years of 1990-1994) is characterized by maximum inflows into the mine as well as the mining of $\mathrm{C}_{8}, \mathrm{C}_{6}, \mathrm{C}_{5}$, and $\mathrm{C}_{4}$ coal seams. The key task of the research stage is to evaluate quantitatively the factors and formation reasons of abnormally high water inflows in terms of the $\mathrm{C}_{5}$ seam.

During the period in which the total mine inflow is $1788 \mathrm{~m}^{3} / \mathrm{h}$, mining takes place within the zone of paleochannel sandstone $\left(C_{8}\right.$ and $C_{5}$ seams) with water conductivity, being comparable with that of the Bucha deposits and in the immediate neighborhood of the Samara River bed (at a $200 \mathrm{~m}$ distance). Analysis of balance components (Table 2) demonstrates that $69 \%$ (i.e., $570 \mathrm{~m}^{3} / \mathrm{h}$ ) of water inflows within the $\mathrm{C}_{5}$ seam is leakage from the Bucha aquifer and river water underrun. Hence, during the period, $40 \%$ of the water inflow into the mine is water filtration from the Samara River.

Table 2. Components of water balance in terms of $C_{5}$ seam.

\begin{tabular}{lc}
\hline \multicolumn{1}{c}{ Expandable Components of the Balance } & Water Inflow Value, $\mathbf{~ m}^{\mathbf{3}} \mathbf{h}$ \\
\hline Mine working-underground water interconnection & 822 \\
(inclusive of leakage from Bucha aquifer at the & $(570)$ \\
expense of filtration from the Samara River) & 0.9 \\
Flow through the level roof & 53.7 \\
Flow through the floor & \\
\hline
\end{tabular}

Consequently, the conical depression displacement in analytical layer one toward the river and underground water, lowering down to $31 \mathrm{~m}$, correspond to the data of monitoring observations in the year of 1994 (Figure 11).

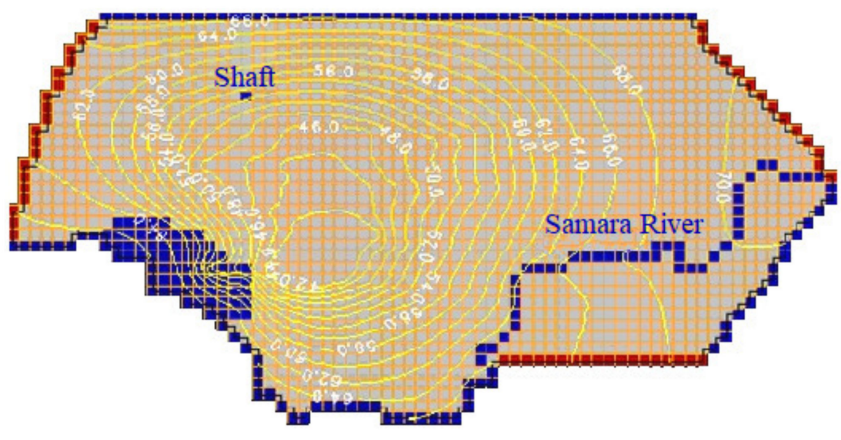

Figure 11. Influence of mining operations on the underground water of overburden deposits for the year of 1994 (according to the modeling results). 
It should be noted that during the time frame, the water intake in the Samara inlet experienced more than a twofold decrease (i.e., from 3200 down to $1800 \mathrm{~m}^{3} /$ day).

Period 3 (years of 1994-1998) is characterized by water inflow lowering down to mine workings (i.e., from 1788 to $1454 \mathrm{~m}^{3} / \mathrm{h}$ ). $\mathrm{C}_{8}, \mathrm{C}_{7}, \mathrm{C}_{6}, \mathrm{C}_{5}$, and $\mathrm{C}_{4}$ coal seams are mined. Water inflow within the main haulage roads of $C_{10}$ seam is recorded. For the period, the decrease in the underground water level of the Bucha-Kyiv deposits is $29 \mathrm{~m}$. In 1995, hydraulic discharge of the Samara water inlet was $180 \mathrm{~m}^{3}$ /day. It was shut down in 1998.

During Periods 4-6, a decrease in the total mine water inflow is lasting (Figure 7) since the mining zone distances from the area where coal seams outcrop under the overburden deposits.

The modeling of the actual dynamics of water inflows and their levels at each stage of the mine field extraction has helped to determine a number of regularities concerning the formation of the underground technogenic mode:

1. If natural water conductivity of coal seams is $0.5-1.5 \mathrm{~m}^{2} /$ day, then actual water inflow values may be achieved when transit zones of hyperpermeability are available. Within a mine field, they are represented by means of sandstone formations with up to $50-60 \mathrm{~m}$ thickness and up to $30 \mathrm{~m}^{2} /$ day water conductivity. The sandstone occurs in the coal seam roof and outcrops under the watered overburden deposits. According to lithological and facial analysis, it is alluvial sandstone of the Early Carboniferous paleochannels; regularities of its spreading over the area correspond to the heightened water ingress during mining.

2. A total of $70 \%$ of the water inflow into a mine are provided from Meso-Cenozoic deposits; $30 \%$ are the capacity reserves of carbonous formation. As a result, the formation of a conical depression up to $30 \mathrm{~m}$ takes place within the Bucha-Kyiv aquifer as well as changes in directions of filtration flows in the neighborhood of the Samara River. Under the disturbed conditions, the river stops being a drainage zone transforming into a feeding zone for overburden deposits. Thus, it becomes an extra source for water mine workings.

3. Movement of the conical depression within the Bucha level performs synchronously by putting into operation a new coal seam toward a zone of outcrop under overburden deposits.

4. Maximum involvement of the Samara River flow in the mine drainage was recorded while extracting the $\mathrm{C}_{5}$ seam within the river plain flood (i.e., at a $200 \mathrm{~m}$ distance from its bed) and while approaching safe mining boundaries. Hence, a maximum of $69 \%$ (i.e., $570 \mathrm{~m}^{3} / \mathrm{h}$ ) of the water inflow within the seam depends upon the river water leakage. The index drops down to $17 \%$ if the mining distances from the coal seam outcrop under the Bucha-Kyiv deposits and the thickness of the underflow decreases within the eastern part of the mine filed.

5. A value of the water inflow into a mine cannot correlate with the increased mining area. Within the area mined out with the roof caving, carbonous formation thickness is a time-variable value which increases 10-15 times in the process of rock displacement. The value decreases after $5-10$ years and stops performing a drainage function after 15-20 years (Figure 12). It is possible to determine such transformations for the specific mining and geological conditions while solving long-term (i.e., during 15-20 years) time series of non-stationary identification problems, being a mandatory stage for the methods developing adequate models of mine fields, and obtaining durable, high-integrity forecasts. 


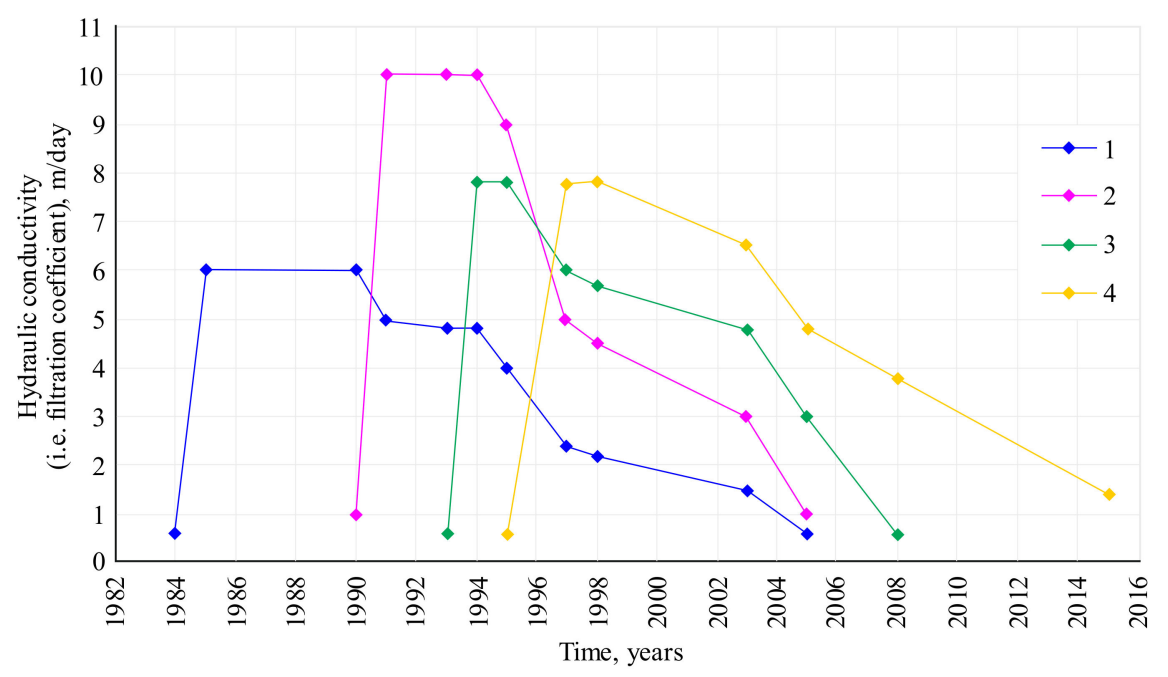

Figure 12. Temporal transformation of filtration properties of the disturbed rock mass (1-4 the year of development).

Relying upon the research results, concerning the temporal transformation of filtration properties of the disturbed rock mass, the authors propose three possible variants of activities to be performed during the phaseout stage to support the drainage mode in the M.I. Stashkov mine as well as a variant to protect a plain flood against waterlogging, while constructing an irrigation intake in a productive formation of paleochannel sandstone with increased hydraulic conductivity.

1. Variant 1. Complete mine flooding.

The dynamics of rock mass flooding differ from the dynamics of level recovery in a mine shaft. Within the stopes of $\mathrm{C}_{10}, \mathrm{C}_{8}$, and $\mathrm{C}_{6}$ seams, flooding lasts during the first year since they are already mined out and levels are recovered partially. The waterlogging of mine shafts and the recovery of the level within $C_{5}$ and $C_{4}$ seams lasts for three years (Figure 13).

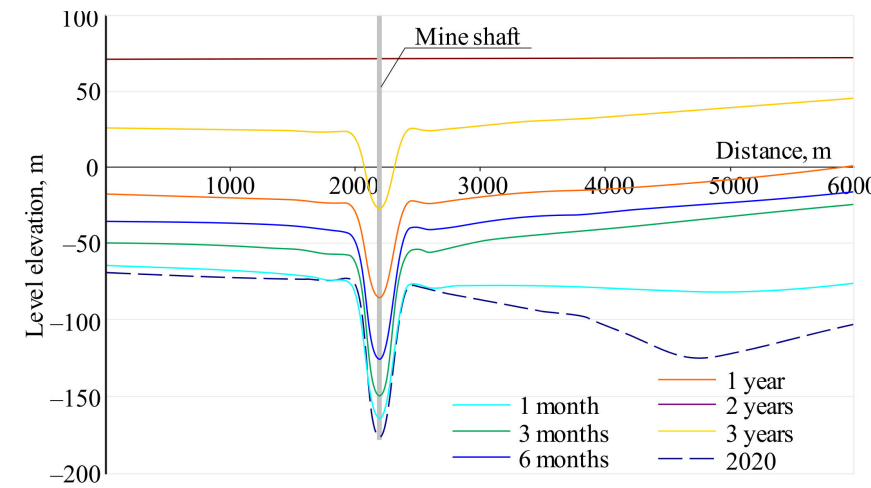

(a)

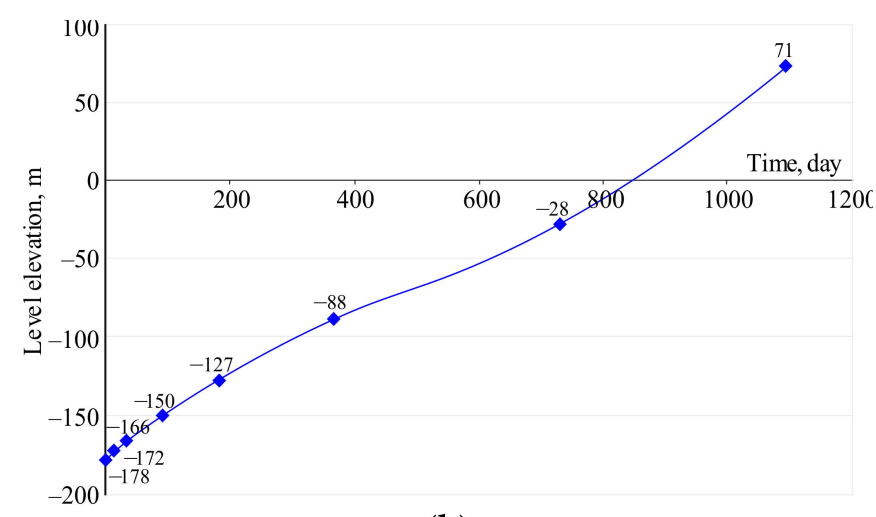

(b)

Figure 13. Dynamics of underground water level recovery in a mine shaft: (a) in terms of east-west section; (b) in time.

The Bucha-Kyiv aquifer response to drainage-off in the mine is manifested as a level recovery over three years with the formation of waterlogging zones along the Samara River bed. The influence of the underground water level recovery on the operation of neighboring mines is seen in the increased water inflow, being $50 \mathrm{~m}^{3} / \mathrm{h}$.

Similar to the preoperational period, the plain flood of the Samara River, with almost a $9.75 \mathrm{~km}^{2}$ area, remains a zone of potential waterlogging and swamping where the absolute 
height is less than $+75 \mathrm{~m}$ (Figure 14). It should be mentioned that the areas were not underworked. They are beyond the zone of geomechanical influence of mining.

2. Variant 2. Mine flooding with preservation of the available underground system of the main mine drainage.

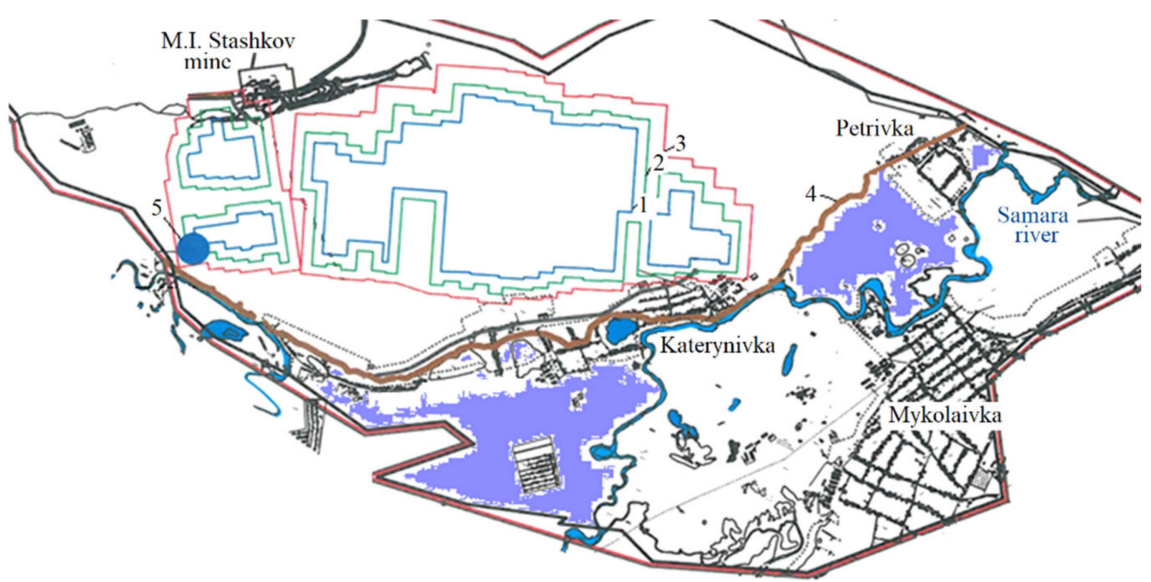

Figure 14. Fragment of the mine field section: 1, 2, 3-projections of $\mathrm{C}_{5}$ seam on a day surface (plane bed, seam periphery, and influence area, respectively); 4-boundary of potential waterlogging; 5-zone of water wells.

Preservation of the main mine drainage at a $225 \mathrm{~m}$ level (elevation is $-115 \mathrm{~m}$ ) helps lower the underground water level from the overburden deposits by $4 \mathrm{~m}$ within the zone of potential (i.e., preoperational) waterlogging. However, in the longer term, the variant involves preservation of the available system for drainage of the mineralized mine water with its further export to the Samara River in the amounts of 5869.2 thousand cubic meters, annually. The fact cannot be considered to be an environmentally friendly measure.

3. Variant 3. The mine abandonment with drainage mode support and by-pit equipping with submersible pumps.

To control the environmental safety of a near-surface aquifer system (i.e., to prevent waterlogging and changes in the underground water as well as in the surface one), it is required to keep underground water marks lower than the foot of overburden deposits within the mining area. To keep the underground mine water level (i.e., underground water of carbonous deposits) within the undermining zone with +20 m elevation being the minimum level of the overburden deposit floor, drainage using submersible pumps is considered in terms of following subvariants.

Mine water elevation levels in a mine shaft are the following:

- $\quad+10 \mathrm{~m}$ with $350 \mathrm{~m}^{3} / \mathrm{h}$ down to $300 \mathrm{~m}^{3} / \mathrm{h}$ discharge;

- $\quad-10 \mathrm{~m}$ with $350 \mathrm{~m}^{3} / \mathrm{h}$ down to $300 \mathrm{~m}^{3} / \mathrm{h}$ drainage discharge;

- $\quad-30 \mathrm{~m}$ with $350 \mathrm{~m}^{3} / \mathrm{h}$ down to $300 \mathrm{~m}^{3} / \mathrm{h}$ discharge.

The response of the overburden deposit aquifer to the operation of the submersible pumps shows that the drainage influence radius is quite smaller, compared with variant 2; within the potential waterlogging area, the level lowering is 0.1 to $1.2 \mathrm{~m}$. In this context, the decrease in the potential waterlogging area is only $15 \%$.

The use of submersible pumps with a drainage rate relative to $225 \mathrm{~m}$ level (elevation is $-115 \mathrm{~m}$ ) or $300 \mathrm{~m}$ level (elevation is $-190 \mathrm{~m}$ ) should involve free water migration from the overlying levels. If the drainage variants are applied, then the situation in the Samara River plain flood is similar to that formed at the final stage of a mine field extraction. However, the abovementioned involves long-term drainage and export of the mineralized mine water to the river. 
4. Variant 4. Alternative to protect the plain flood against waterlogging by means of water storage facility construction within the productive strata of paleochannel sandstone being of heightened hydraulic conductivity.

Substantiation of the variant as well as the water well location follows the solution of the identification problems and practices of $\mathrm{C}_{5}$ seam mining in the immediate neighborhood of its outcrop under overburden deposits and the Samara River bed. During 1994-1995, abnormal water inflows into the mine were recorded (i.e., $1817 \mathrm{~m}^{3} / \mathrm{h} ; 822 \mathrm{~m}^{3} / \mathrm{h}$ of them within $C_{5}$ seam); the level of the Bucha deposits achieved $30 \mathrm{~m}$. In this context, the paleochannel sandstone, occurring in the main roof of the $C_{5}$ seam with $14-22 \mathrm{~m}$ thickness, served as an extra zone for the transition of the underground water of overburden deposits.

Defining the reasons and factors of abnormal water inflow manifestation makes it possible to use the disturbed zone of the underflow sandstone within a -55 to $-50 \mathrm{~m}$ elevation range to reduce natural waterlogging areas after mine abandonment. Figure 14 demonstrates the well location in the plan.

Sufficient lowering of the level within a potential waterlogging area (i.e., up to $2 \mathrm{~m}$ ) is recorded if wells with a total of $150 \mathrm{~m}^{3} / \mathrm{h}$ or $3600 \mathrm{~m}^{3} /$ day operate. According to the dynamics of mine field flooding, its operation should be foreseen after 6 months from the onset of the mine field flooding. The average mineralization of the water to be pumped out will be almost $2 \mathrm{~g} / \mathrm{dm}^{3}$.

The variant is the most acceptable, ecologically, with synchronous level mode monitoring, which will help use the industrial water for internal needs of the mine office as well as increase the reclaimed land area up to $90 \%$.

\section{Conclusions}

As a result of the carried out complex of scientific studies, the paper helped to solve topical problems related to the scientific substantiation of a scheme of a geofiltration model of a mine field, taking into consideration both natural and technogenic factors of underground water mode formation. This was possible owing to solving nonstationary identification problems and determining regularities of the rock mass hydraulic conductivity transformation (involving a numerical model), being of scientific and applied value.

It is possible to forecast underground water dynamics within the technogenic environment of a mine field if a permanent numerical model is developed. The model is identified using reconstruction of the whole hydrodynamic history of deposit mining in terms of characteristic time periods.

The determined regularities of changes in the technogenic hydraulic conductivity of a mine field of rock mass increase the validity of long-term hydrodynamic forecasts, making it possible to develop technological procedures for water control. The hydrodynamic model of the M.I. Stashkov mine field is an integral part of the geofiltration model of a share of the Donetsk coal basin (Western Donbas) for solving the current problems of water control as well as the environmentally friendly process of mining phaseout.

According to the forecast analysis, in the context of the recovery of the underground water level of carbonous and overburden deposits, areas of potential waterlogging and swamping are formed in the Samara River plain food, which existed during the preoperational period. The areas were not underworked; moreover, they are beyond the zone of geomechanical influence of the mining operations.

Alternatives to the support drainage mode in the M.I. Stashkov mine were considered as well as an option to protect the floodplain against waterlogging by means of water storage facility construction within the productive strata of the paleochannel sandstone, being of heightened hydraulic conductivity. Three variations to support mine drainage were proposed as engineering measures to protect the river plain flood against waterlogging. The use of submersible pumps for water pumping out from the mine shaft over $140 \mathrm{~m}$ level is an inefficient procedure from the viewpoint of a decrease in waterlogging areas since they are within the mine field periphery. Drainage support at the $225 \mathrm{~m}$ level makes it possible to approach the hydrogeological situation, being typical for the deposit mining 
period; however, it involves long-term drainage of the mineralized mine water and its discharge to the Samara River.

The substantiation of water storage facility construction has become possible, owing to solving epignosis problems for a period of abnormally high inflows into the mine. The abovementioned helps use the productive formation of paleochannel sandstone within the $\mathrm{C}_{5}$ seam roof as a transit zone of heightened hydraulic conductivity to protect the plain flood against waterlogging. The results of the forecasting hydrodynamic solutions concerning the mine flooding outcomes are the foundations to develop its abandonment project.

A hydrodynamic model of the M.I. Stashkov mine field will become a constituent part to develop a regional hydrodynamic Western Donbas model. It is planned to use the regional model for studying and considering the regional water balance control alternatives in terms of the mining closure to minimize environmental risks and substantiate the geocirculation of the heat supply systems with the use of capacity resources of the flooded mine fields.

Author Contributions: Conceptualization, I.S. and A.Z.; methodology, I.S.; software, A.Z.; validation, P.S., V.L. and R.D.; formal analysis, A.Z.; investigation, I.S. and A.Z.; resources, P.S. and V.L.; data curation, R.D.; writing—original draft preparation, I.S.; writing—review and editing, A.Z.; visualization, V.L.; supervision, O.B.; project administration, O.B.; funding acquisition, O.B. All authors have read and agreed to the published version of the manuscript.

Funding: This study was carried out as part of the project "Belt and Road Initiative Institute for Chinese-European studies (BRIICES)" and was funded by the Guangdong University of Petrochemical Technology.

Institutional Review Board Statement: Not applicable.

Informed Consent Statement: Not applicable.

Data Availability Statement: Data are contained within the article.

Acknowledgments: The authors express appreciation to the company for its assistance in the research pursuance and implementation of its findings.

Conflicts of Interest: The authors declare no conflict of interest.

\section{References}

1. Anpilova, Y.; Yakovliev, Y.; Drozdovych, I. Landscape and geological factors of water and ecological conditions technogenesis of donbas at the post-mining stage. In Proceedings of the Geoinformatics: Theoretical and Applied Aspects, Kyiv, Ukraine, 11-14 May 2010; pp. 1-5.

2. Timoshuk, V.; Demchenko, J.; Sherstuk, Y. The role of natural and technogenic components in failure of geomechanical stability of the territories which are in the influence zone of mining objects. New Tech. Technol. Min. 2010, 189-192. [CrossRef]

3. Lozynskyi, V.; Medianyk, V.; Saik, P.; Rysbekov, K.; Demydov, M. Multivariance solutions for designing new levels of coal mines. Rudarsko-Geološko-Naftni Zbornik 2020, 35, 23-32. [CrossRef]

4. Malvić, T.; Ivšinović, J.; Velić, J.; Sremac, J.; Barudžija, U. Increasing Efficiency of Field Water re-injection during water-flooding in mature hydrocarbon reservoirs: A Case study from the Sava depression, Northern Croatia. Sustainability 2020, 12, 786. [CrossRef]

5. Popovych, V.; Stepova, K.; Voloshchyshyn, A.; Bosak, P. Physico-Chemical Properties of Soils in Lviv Volyn Coal Basin. In Proceedings of the IVth International Innovative Mining Symposium, Kemerovo, Russia, 14-16 October 2019.

6. Gorova, A.; Pavlychenko, A.; Borysovs'ka, O. The study of ecological state of waste disposal areas of energy and mining companies. Min. Miner. Depos. 2013, 169-172. [CrossRef]

7. Buzylo, V.; Pavlychenko, A.; Savelieva, T.; Borysovska, O. Ecological aspects of managing the stressed-deformed state of the mountain massif during the development of multiple coal layers. E3S Web Conf. 2018, 60, 00013. [CrossRef]

8. Keqiang, H.; Zhiliang, W.; Xiaoyun, M.; Zengtao, L. Research on the displacement response ratio of groundwater dynamic augment and its application in evaluation of the slope stability. Environ. Earth Sci. 2015, 74, 5773-5791. [CrossRef]

9. Bentabet, A.; Azzaz, H.; Emblanch, C.; Benamina, B. The impact of agricultural development on karstic groundwater of the Saïda mountains, Algeria. Rudarsko-Geološko-Naftni Zbornik 2019, 34, 97-105. [CrossRef]

10. Saba, T.; Illangasekare, T.H. Effect of groundwater flow dimensionality on mass transfer from entrapped nonaqueous phase liquid contaminants. Water Resour. Res. 2000, 36, 971-979. [CrossRef]

11. Kovač, Z.; Nakić, Z.; Barešić, J.; Parlov, J. Nitrate origin in the Zagreb aquifer system. Geofluids 2018, 1-15. [CrossRef]

12. Culver, T.B.; Hallisey, S.P.; Sahoo, D.; Deitsch, J.J.; Smith, J.A. Modeling the desorption of organic contaminants from long-term contaminated soil using distributed mass transfer rates. Environ. Sci. Technol. 1997, 31, 1581-1588. [CrossRef] 
13. Huljek, L.; Perković, D.; Kovač, Z. Nitrate contamination risk of the Zagreb aquifer. J. Maps 2019, 15, 570-577. [CrossRef]

14. Tikhonov, V.; Karaeva, T.; Ushakova, E. The geosystem basis environmental of safe disposal of the objects of mining complex. In Proceedings of the International Multidisciplinary Scientific GeoConference SGEM2014, Science and Technologies in Geology, Exploration and Mining, Albena, Bulgaria, 19-25 June 2014. [CrossRef]

15. Li, X.; Li, S.; Chen, J.; Liao, Q. Coupling effect mechanism of endogenic and exogenic geological processes of geological hazards evolution. Chin. J. Rock Mech. Eng. 2008, 27, 1792-1806.

16. Popovych, V.; Stepova, K.; Prydatko, O. Environmental hazard of Novoyavorivsk municipal landfill. MATEC Web Conf. 2018, 247, 00025. [CrossRef]

17. Sdfbg Nathoo, J.; Gay, E.H.; Hussain, N. Development of a predictive model to determine the temporal variability in mine feed water quality towards informing and forecasting plant operating strategy-A South African coal mine water treatment plant case study. Water Pract. Technol. 2016, 11, 621-633. [CrossRef]

18. Fan, G.; Zhang, S.; Zhang, D.; Zhang, C.; Chen, M.; Li, Q. An index of aquiclude destabilization for mining-induced roof water inrush forecasting: A case study. Water 2019, 11, 2170. [CrossRef]

19. Nakić, Z.; Mileusnić, M.; Pavlić, K.; Kovač, Z. Environmental geology and hydrology. Phys. Sci. Rev. 2017, 2, 20160119. [CrossRef]

20. Dfbg Kang, J.; Hu, Y. Forecasting and preventing of water calamity in underground engineering of mine. J. Liaoning Tech. Univ. Nat. Sci. Ed. 2001, 20, 758.

21. Liu, X.; Wang, S. Mine water inrush forecasting during the mining under waters. Disaster Adv. 2012, 5, 877-882.

22. Dychkovskyi, R.; Shavarskyi, I.; Saik, P.; Lozynskyi, V.; Falshtynskyi, V.; Cabana, E. Research into stress-strain state of the rock mass condition in the process of the operation of double-unit longwalls. Min. Miner. Depos. 2020, 14, 85-94. [CrossRef]

23. Khomenko, O.; Barna, T. Zonal-and-wave structure of open systems on micro, mega- and macrolevels of the universe. Philos. Cosmol. 2019, 22, 24-32. [CrossRef] [PubMed]

24. Vladyko, O.; Kononenko, M.; Khomenko, O. Imitating modeling stability of mine workings. Geomech. Process. Undergr. Min. 2012, 147-150. [CrossRef]

25. Abdiev, A.; Mambetova, R.; Abdiev, A.; Abdiev, S. Studying a correlation between characteristics of rock and their conditions. Min. Miner. Depos. 2020, 14, 87-100. [CrossRef]

26. Malanchuk, Z.; Malanchuk, Y.; Korniyenko, V.; Ignatyuk, I. Examining features of the process of heavy metals distribution in technogenic placers at hydraulic mining. East. Eur. J. Enterp. Technol. 2017, 85, 45-51. [CrossRef]

27. Malanchuk, Y.; Korniienko, V.; Moshynskyi, V.; Soroka, V.; Khrystyuk, A.; Malanchuk, Z. Regularities of hydromechanical amber extraction from sandy deposits. Min. Miner. Depos. 2019, 13, 49-57. [CrossRef]

28. Ursul, A.; Ursul, T. Environmental education for sustainable development. Future Hum. Image 2018, 9, 115-125. [CrossRef]

29. Dubrova, N.A. Evaluating changes in filtration properties of deformable rock mass resulting from the repeated undeworking. Visnyk Krnu 2014, 1, 96-106.

30. Podvigina, O.O. On the changes in hydrogeological situation under the conditions of mine flooding in the Central Donbas part based upon modelling. Collect. Sci. Pap. UkrGPI 2007, 1, 92-98.

31. Chetveryk, M.S.; Androshchuk, Y.V. Theory of Rock Mass Displacement and Deformational Process Control in the Context of Underground Coal Mining; RIA Dnepr-VAL: Dnipropetrovsk, Ukraine, 2004; p. 148.

32. Rudakov, D.V.; Ivanova, Y.S. Geomechanical assessment of the fissured rock permeability around underground mine workings. Naukovyi Visnyk Natsionalnoho Hirnychoho Universytetu 2012, 2, 49-53.

33. Yelchaninov, Y.A.; Golovko, I.V. Formation of secondary underground aquifers after abandonment of mines. Gorn. Inf. Anal. Byulleten 2007, 8, 147-152.

34. Perkova, T.I.; Rudakov, D.V. Study of leaching in fractured rocks affected by mineralized mine water. Naukovyi Visnyk Natsionalnoho Hirnychoho Universytetu 2014, 5, 5-10.

35. Sadovenko, I.; Inkin, O.; Zagrytsenko, A. Theoretical and geotechnological fundamentals for the development of natural and man-made resources of coal deposits. Min. Miner. Depos. 2016, 10, 1-10. [CrossRef]

36. Rudakov, D.; Inkin, O.; Dereviahina, N.; Sotskov, V. Effectiveness evaluation for geothermal heat recovery in closed mines of Donbas. E3S Web Conf. 2020, 201, 01008. [CrossRef]

37. Mendygaliyev, A.; Arshamov, Y.; Selezneva, V.; Yazikov, E.; Bekbotayeva, A. Prospects for application of multi-spectral earth sensing data in forecasting and searching for reser-voir-infiltration uranium deposits. News Natl. Acad. Sci. Repub. Kazakhstan 2021, 446, 90-97. [CrossRef]

38. Khalymendyk, I.; Baryshnikov, A. The mechanism of roadway deformation in conditions of laminated rocks. J. Sustain. Min. 2018, 17, 41-47. [CrossRef]

39. Babets, D.V.; Sdvyzhkova, O.O.; Larionov, M.H.; Tereshchuk, R.M. Estimation of rock mass stability based on probability approach and rating systems. Naukovyi Visnyk Natsionalnoho Hirnychoho Universytetu 2017, 2, 58-64.

40. Shashenko, A.; Gapieiev, S.; Solodyankin, A. Numerical simulation of the elastic-plastic state of rock mass around horizontal workings. Arch. Min. Sci. 2009, 54, 341-348.

41. Sadovenko, I.; Ulytsky, O.; Zahrytsenko, A.; Boiko, K. Risk assessment of radionuclide contamination spreading while flooding coal mined-out rocks. Min. Miner. Depos. 2020, 14, 130-136. [CrossRef]

42. Sadovenko, I.; Rudakov, D.; Podvigina, O. Analysis of hydrogeodynamics in a mining region during exploitation till closure of coal mines. New Tech. Technol. Min. Sch. Undergr. Min. 2010, 61-69. [CrossRef] 
43. Purgina, D.; Kuzevanov, K.; Burmakova, E. Hydrogeological conditions of potable water supply the Kuznetsk Coal Basin, Russia. E3S Web Conf. 2019, 98, 09024. [CrossRef]

44. Sadovenko, I.A.; Inkin, A.V.; Rudakov, D.V.; Hriplivets, J.V. Modeling of the flooding process of the mine "Novogrodovskaya No $2 "$ to assess the possibility of using its heat source. Izv. Ural. Gos. Gorn. Univ. 2014, 33, $29-37$.

45. Armenat, M.; Malek, K. The underground world heritage site in the harz mining region. Z. Geomorphol. 2021, 62, $265-281$. [CrossRef]

46. Luo, A.K.; Hou, Y.; Hu, X.Y. Mining influence on underground water resources in arid and semiarid regions. In IOP Conference Series: Earth and Environmental Science; IOP Publishing: Bristol, UK, 2018. [CrossRef]

47. Lyashenko, V.I.; Golik, V.I.; Dyatchin, V.Z. Increasing environmental safety by reducing technogenic load in mining regions. Izv. Ferr. Metall. 2020, 63, 529-538. [CrossRef]

48. Scheidler, S.; Huggenberger, P.; Dresmann, H.; Auckenthaler, A.; Epting, J. Regional groundwater flow and karst evolutiontheoretical approach and example from Switzerland. Environ. Earth Sci. 2021, 80, 201. [CrossRef]

49. Kirin, R. Statutory and regulatory requirements in the process of mineral mining in Ukraine. Review and analysis. Min. Miner. Depos. 2019, 13, 59-65. [CrossRef]

50. Bazaluk, O.; Petlovanyi, M.; Lozynskyi, V.; Zubko, S.; Sai, K.; Saik, P. Sustainable underground iron ore mining in Ukraine with backfilling worked-out area. Sustainability 2021, 13, 834. [CrossRef]

51. Ursul, A.; Tirdea, T.; Ursul, T. Limits to Growth and Achievement of Global Sustainability. Philos. Cosmol. 2018, 21 , 42-51. [CrossRef]

52. Haiko, H.; Saik, P.; Lozynskyi, V. The philosophy of mining: Historical aspect and future prospect. Philos. Cosmol. 2019, 22, 76-90. [CrossRef]

53. Popovych, V.; Telak, J.; Telak, O.; Malovanyy, M.; Yakovchuk, R.; Popovych, N. Migration of Hazardous Components of Municipal Landfill Leachates into the Environment. J. Ecol. Eng. 2020, 21, 52-62. [CrossRef]

54. Younger, P.L.; Banwart, S.A.; Hedi, R.S. Mine Water: Hydrology, Pollution, Remediation; National Groundwater Association: Westerville, OH, USA, 2002; p. 442.

55. Wolkersdorfer, C. Water Management at Abandoned Flooded Underground Mines. Fundamentals. Tracer Tests. Modelling. Water Treatment; Springer: Berlin, Germany, 2008; p. 465.

56. Rybnikova, L.S.; Rybnikov, P.A. Geofiltration rock mass model within the area of operating and being liquidated mines of the folded Ural mountains. Litosfera 2013, 3, 130-136.

57. Sadovenko, I.; Zagrytsenko, A.; Podvigina, O.; Dereviagina, N. Assessment of environmental and technical risks in the process of mining on the basis of numerical simulation of geofiltration. Min. Miner. Depos. 2016, 10, 37-43. [CrossRef]

58. Petlovanyi, M.V.; Lozynskyi, V.H.; Saik, P.B.; Sai, K.S. Modern experience of low-coal seams underground mining in Ukraine. Int. J. Min. Sci. Technol. 2018, 28, 917-923. [CrossRef]

59. Petlovanyi, M.; Malashkevych, D.; Sai, K.; Zubko, S. Research into balance of rocks and underground cavities formation in the coal mine flowsheet when mining thin seams. Min. Miner. Depos. 2020, 14, 66-81. [CrossRef]

60. Bear, J.; Verruijt, A. Modeling Groundwater Flow and Polluyion; Springer: Berlin, Germany, 1998; p. 414.

61. Kinzelbach, W. Groundwater Modeling (An Introduction with Sample Programs in BASIC); Elsevier: Amsterdam, The Netherlands, 1986.

62. Zahrytsenko, A.; Podvigina, O.; Dereviahina, N. Scientific and methodological foundations to develop numerical hydrodynamical models of mine fields in Donbas. E3S Web Conf. 2018, 60, 00034. [CrossRef]

63. Zelenska, L.I.; Yevhrashkina, H.P. Ekoloho-hidroheolohichni problemy terytorii, pryliahaiuchykh do khvostoskhovyshch Kryvorizkoho zalizorudnoho baseinu ta shliakhy yikh rishennia. J. Geol. Geogr. Geoecol. 2011, 19, 1. 